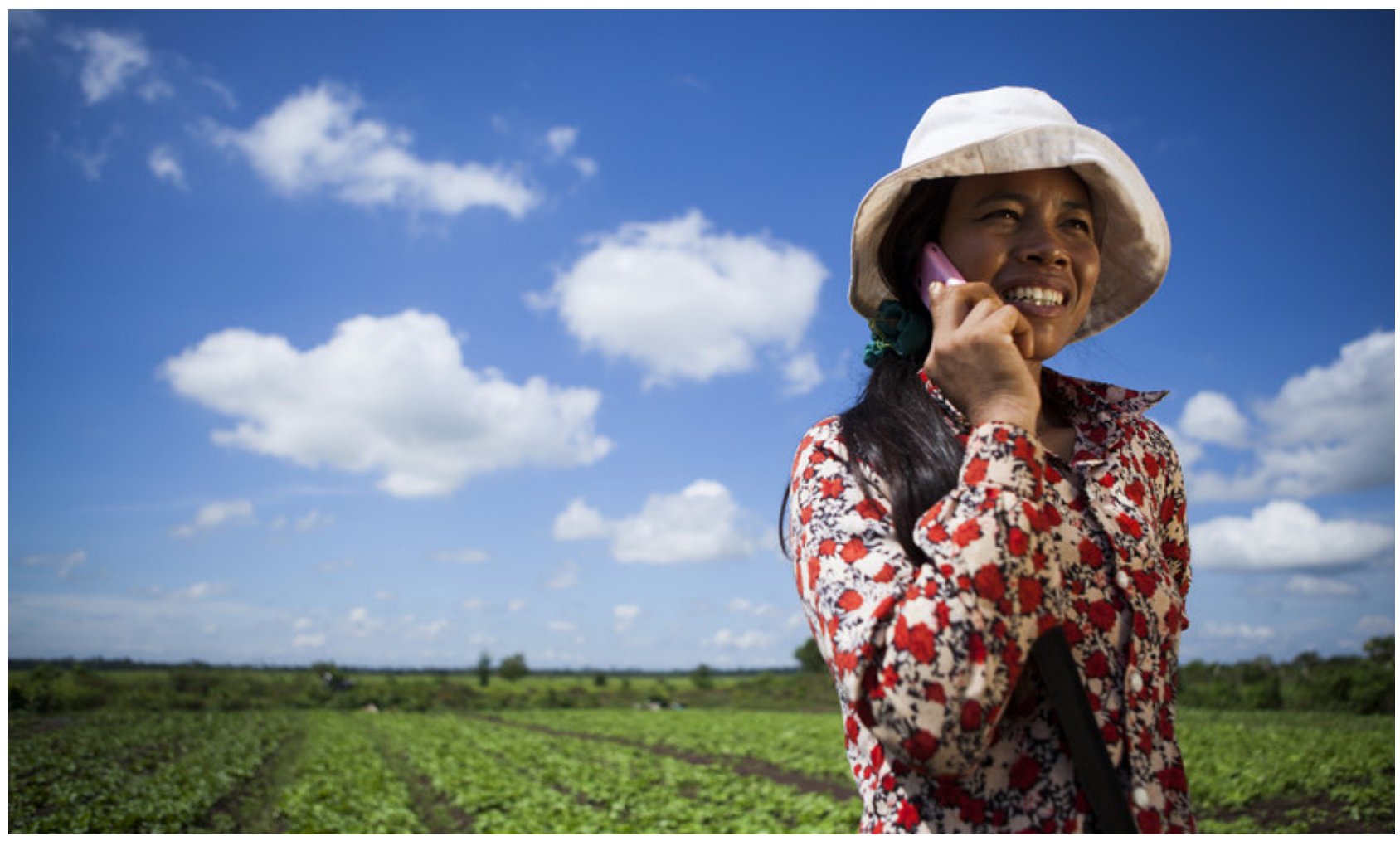

Oxfam's Pink Phones project in Cambodia involves the distribution of mobile phones to women in rural communities. The phones enable them to gain access to vital farming information such as market prices for their crops and weather information.. Photo: Simon Rawles/Oxfam

\title{
MISSING OUT ON SMALL IS BEAUTIFUL \\ The EU's failure to deliver on policy commitments to support smallholder agriculture in developing countries
}

With the world on the brink of an unprecedented four famines, donor countries must urgently step up efforts to tackle the structural causes of hunger and poverty. Food security and sustainable agriculture are among the European Union's key priorities for development cooperation. The EU is committed to longterm solutions, including empowering smallholders, in particular women, and supporting environmentally sustainable approaches in agriculture. In practice, however, its development aid to the agricultural sector does not live up to its commitments. An Oxfam analysis of more than 7,500 EU-funded projects reveals a significant lack of transparency in reporting, casting doubt on the accountability of the EU's aid. Based on the reported data, only a small portion of the EU's agricultural development aid complies with the aim of targeting small-scale producers and women. Funding is also biased towards industrial and export crops and countries of strategic interest, at the expense of smallholders and countries most in need. 
In 2017, less than 10 years after the 2007-08 food price crisis, the world stands on the brink of an unprecedented four famines. Famine has already been declared in South Sudan, while Nigeria, Yemen and Somalia are also facing the risk of mass starvation. These are just four of the dozens of countries confronting acute and widespread food insecurity. ${ }^{1}$ Globally, an estimated 795 million people - one in nine worldwide - are still going hungry. ${ }^{2}$ The reasons for this are many, including high food prices, low agricultural productivity, abnormal weather patterns and conflict. Yet the scale of food insecurity points to deeper problems in the global food system that have never been adequately tackled. Social and economic exclusion, structural poverty, lack of access to productive resources such as land, and imbalances in power are consigning millions of people to hunger.

There is significant agreement on the need for greater commitment to address the longterm structural causes of food insecurity - and solutions are known. Empowering smallholders and supporting their efficient and environmentally sustainable approaches to agriculture is a proven long-term solution to reducing hunger and poverty and tackling power imbalances and inequalities. At least $\mathbf{4 7 5}$ million small-scale farms worldwide support around two billion people, ${ }^{3}$ and investing in the sector is known to have immense potential for reducing poverty. Women play a potentially transformative role in agricultural development, but they continue to face social, cultural and economic constraints that limit their potential in the sector.

European Union policy makers are aware of both the challenges and the solutions. The role of agriculture was recognized as being crucial for poverty reduction in the 2005 European Consensus on Development. Responding to some of the most severe global food price crises from 2007 onwards, the EU launched the $€ 1$ bn Food Facility, with a specific focus on small-scale producers, in 2009 and the Food Security Policy Framework (FSPF) in 2010. Through the FSPF, the EU committed to a rights-based approach to support small-scale food producers, gender mainstreaming and ecologically sustainable approaches. Since then, it has made further policy commitments to reinforce priorities established in 2010; an Implementation Plan has been produced, and the European Commission has compiled consolidated EU-wide biennial progress reports since 2014. The new European Consensus on Development, adopted in May 2017, reiterates the central importance of smallholder farmers.

However, Oxfam's analysis of the EU's official development assistance (ODA) for agriculture reveals that its investments do not match its policy priorities. On average, the EU's financial support for the three priority areas of smallholders, gender equality in agriculture and ecological sustainability is strikingly low. An analysis of preimplementation project data shows that less than one-quarter of EU aid for agriculture explicitly targets small-scale producers. Only 2-3 percent of EU funding promotes gender equality in agriculture, while ecological sustainability is largely missed out in planning documents altogether. Furthermore, with the exception of just one year, EU ODA has consistently supported industrial and export crops with significantly higher budgets than food crops.

Finally, Oxfam's analysis of EU development funding for agriculture suggests that ODA is being instrumentalized to support EU foreign policy goals instead of responding to the actual needs of the most marginalized people. There is a clear bias towards supporting potential candidates for EU membership and the European neighbourhood regions, to 


\section{ANALYSING 7,500 DEVELOPMENT PROJECTS}

\section{FRAMEWORK FOR THE ANALYSIS AND RESEARCH PROCESS}

Oxfam and the Medical Mission Institute (MMI - based in Würzburg, Germany) established a research collaboration to track the EU's ODA grants in the agriculture sector. The research, which had a focus on funding managed by the EC (through DG DEVCO), set out to answer a number of questions on the EU's performance: i.e. how were its budget commitments and disbursements of agricultural ODA between 2007 and 2015 aligned with the five priorities identified in its policy documents - stable and increasing overall flows, a focus on smallholder farmers, gender equality, ecological sustainability and needs-based disbursement? Oxfam and MMI compared the consolidated quantitative evidence from their research with the EU's policy commitments. This briefing note summarizes the outcomes.

Figure 1: Main analytical categories

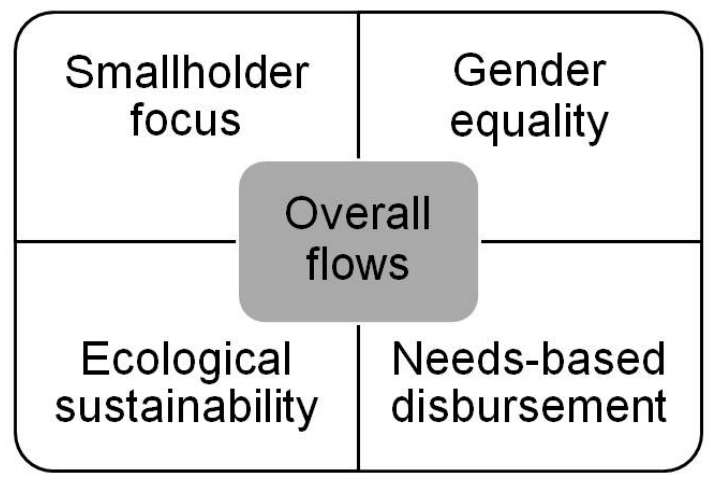

The study was performed in two phases. In the first phase, all agriculture-related projects were identified in the Creditor Reporting System (CRS) database of the Development Assistance Committee of the Organisation for Economic Co-operation and Development (OECD DAC). This was done by including all of the projects officially reported in sectors relevant to agriculture (i.e. Agriculture, Food Security, Rural Development, and also General Budget Support), as well as additional projects identified through a keyword search, regardless of the sector under which they were reported in the CRS. Of the total 66,750 individual projects that the EU supported in the years 2007-15, 7,531 were found to support agriculture, and so were the object of further analysis. Because of the insufficiency of information reported to the CRS, Oxfam and MMI resorted to the International Aid Transparency Initiative (IATI) database, planning documents and other sources in order to correctly classify the projects according to agricultural sub-sectors, to quantify the respective proportion going to agriculture and to examine the significance of the policy objectives. A focus on smallholders, gender equality or ecological sustainability was classified either as a 'principal' objective (> 50 percent of total funding) or a 'significant' objective (<50 percent of total funding), or non-existent as an objective in each project. In the second phase, the researchers performed an in-depth analysis of a sample of $25 \mathrm{EU}$-funded agriculture projects in Africa by examining their evaluation 
reports. The ex-post information contained in these reports allowed them to draw a more complete and accurate picture of the project objectives and activities, compared with planning documents or simply relying on official reporting. ${ }^{4}$

The research provides a thorough indication of the EU's funding trends and priorities. However, the following limitations apply. In the first phase of the research, for 11 percent of the agriculture-related projects appropriate information was completely missing in the CRS database, though the possible effect of this on the estimation result is minor. However, even for the remaining 89 percent of projects, the existing information systems on aid activities are not designed to indicate the target groups, let alone the respective budget shares. Therefore, presentation of the detailed proportional funding for the defined policy objectives in the following sections needs to be interpreted with some caution. The second phase of the research, while based on only 25 projects, generated enough information to conclude some preliminary findings. In fact, the in-depth analysis shows that many project evaluations took into account certain policy objectives that were not referred to in planning documents. For instance, according to the results in the first phase, funding destined for supporting smallholders ranged between only 18 percent and 30 percent, while the in-depth analysis shows that 76 percent of projects in the sample did aim to strengthen small-scale farming through at least one component. The problem of limited and inaccurate reporting in the CRS database and planning documents represents not only a limitation to this analysis, but even more importantly points to a lack of transparency and accountability on aid activities financed through the EU. Despite these limitations, however, triangulation of the two research phases enable trends to be identified in EU development aid for agriculture towards the policy priorities mentioned above. $^{5}$

\section{STRONG FLUCTUATIONS AND SKEWED TARGETING OF EU AGRICULTURAL AID}

'The Council calls on the EU and its Member States to increase the support to agriculture, food security and nutrition.' - European Commission: EU policy framework on food security ${ }^{6}$

'Effective future planning is reliant on predictable resource flows.' - United Nations, Development Initiatives, UK Aid ${ }^{7}$

More and consistent investment in agriculture is required if the sector is to deal with a growing list of challenges, from rural poverty to climate change. Recent research has concluded that ending hunger worldwide by 2030 can be achieved with an extra $\$ 11 \mathrm{bn}$ per year of public spending - a substantial, yet affordable amount. ${ }^{8}$ Of that total, $\$ 4 \mathrm{bn}$ would need to come from international donors, while the remaining $\$ 7 \mathrm{bn}$ would come from the affected countries themselves.

In 2003, under the Maputo Declaration on Agriculture and Food Security, African Union (AU) nations made a commitment to allocate a minimum of 10 percent of their national budgets to agricultural development. This political pledge was reiterated in the Malabo Declaration a decade later. ${ }^{9}$ For its part, the EU responded quickly to the 2007-08 food price crisis with the $\$ 1$ bn Food Facility, launched in partnership with the UN Food and Agriculture Organization (FAO) in 2009 and designed to help developing countries move towards long-term food security. The 2010 EU Food Security Policy Framework sealed the commitment to tackling the root causes in the long term. 
Sadly, investment in agriculture in developing countries has not met the envisioned increase. The annual amounts committed by the EU spiralled to $\$ 1.4 \mathrm{bn}$ in 2009 , due to the Food Facility, but fell to just half of that level only two years later. While recognizing that 'effective future planning is reliant on predictable resource flows' ${ }^{10}$ the reality of EU ODA flows to agriculture is enormous fluctuations that impede long-term planning to reach goals. A closer look at the sub-sectors of ODA flows reveals that support for food crop production is subject to wide variations and a pronounced tendency of decline after the short-lived peak in 2009 and 2010. Except in 2009, EU ODA has consistently supported industrial and export crops with significantly higher budgets than food crops. This raises the question of whether the most socially and economically marginalized farmers are able to benefit or whether these projects benefit mostly those who are already better off and have existing market connections. In the absence of public safety nets, it is also questionable whether farmers who specialize in one or a few industrial/export crops are able to cope with market or price fluctuations and the resulting impacts on household food security.

These findings show that the EU is not meeting its bold policy commitments to ensure stable and sufficient support to agriculture for long-term food security and resilient livelihoods. Sometimes partner countries perform no better. Only 13 out of 54 countries in Africa have met the Malabo commitment of devoting 10 percent of their spending to agriculture in one or more years since $2003 .^{11}$ The share of agriculture in the general budget support provided by the EU is also very low, at approximately 2-4 percent. Of 30 countries receiving general budget support from the EU in 2015, seven used less than 1 percent of total public resources to promote agricultural development. These modest shares point to a need to urgently step up efforts to unlock the significant potential that investing in agriculture holds. This should entail placing governance issues at the core of EU policy dialogue with partner countries, taking into account the local socio-political context in EU programming in order to better address the underlying causes fomenting food and nutrition insecurity. 
Figure 2: Overall flows of EU ODA for agriculture

EU: Bilateral ODA Grants for Agriculture by Reported Sectors, Euro million

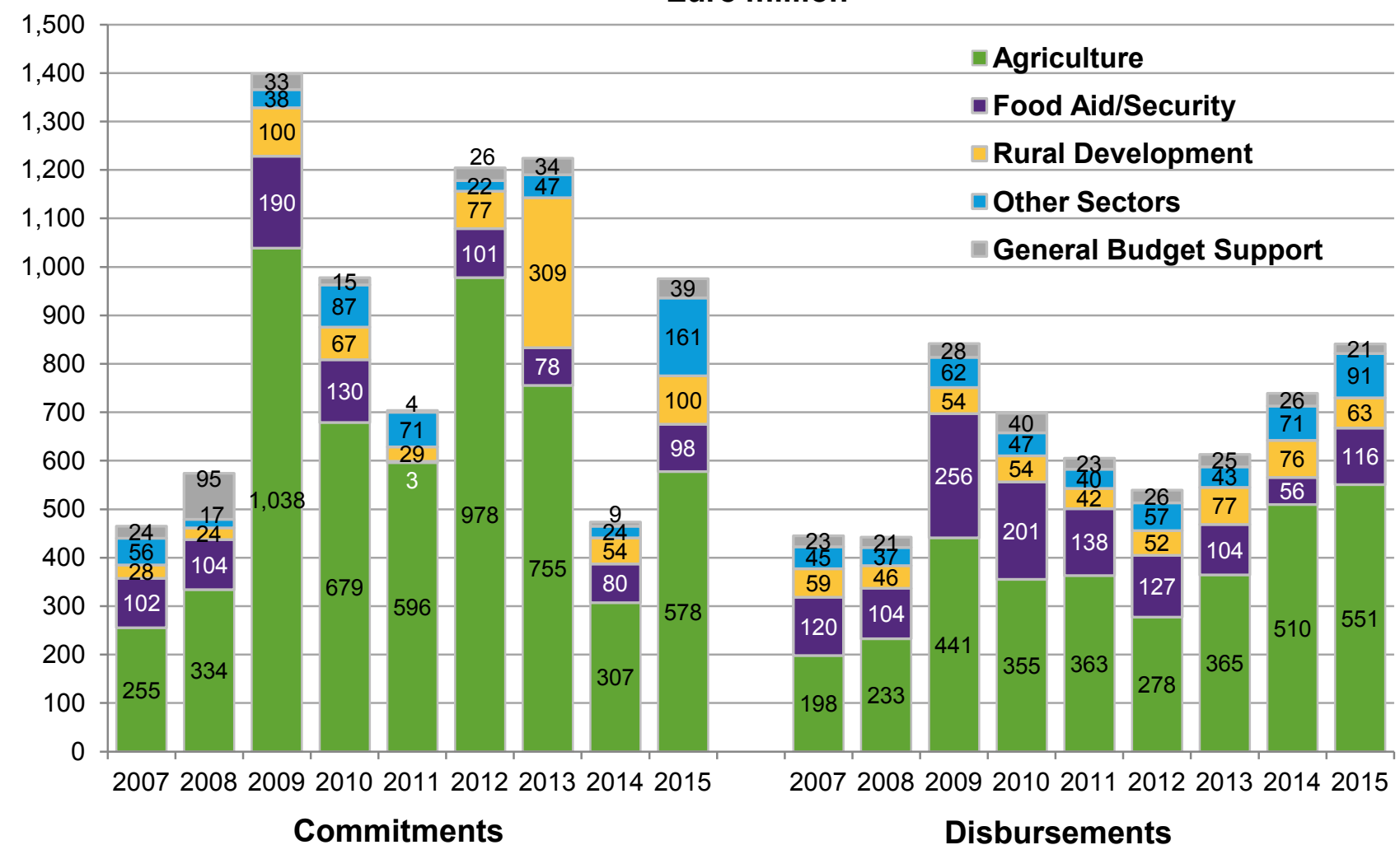

Figure 3: EU ODA grants for agriculture by sub-sector

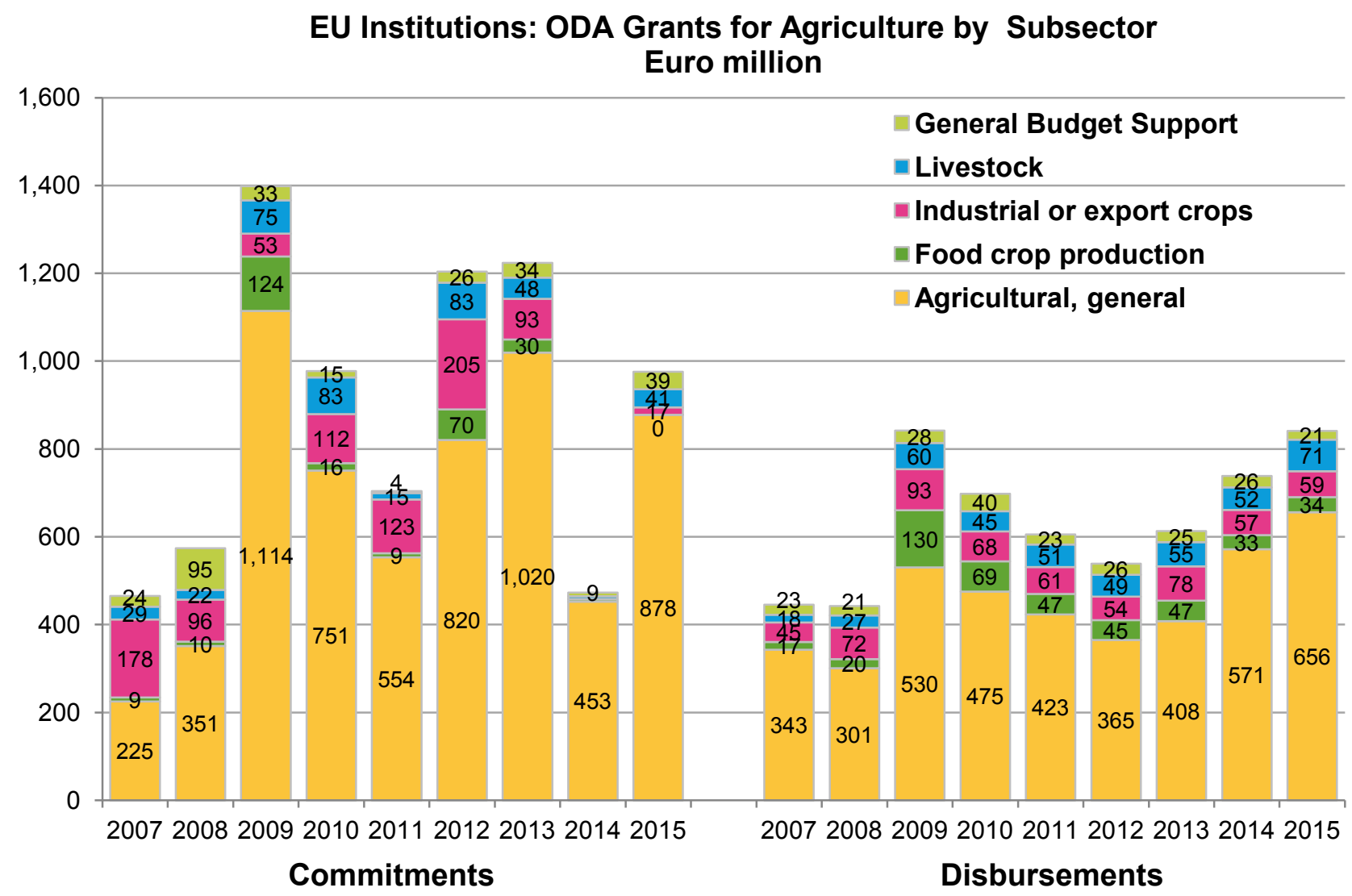




\section{LACK OF SMALLHOLDER FOCUS CONTRADICTS POLICY COMMITMENTS}

'Evidence shows that investments in the smallholder sector yield the best returns in terms of poverty reduction and growth. This new EU framework [on food security] therefore concentrates on enhancing incomes of smallholder farmers.' - European Commission: EU policy framework on food security ${ }^{12}$

Attracting investment is not an end in itself, but a means to an end. The quality of the investment matters too. Sustainable agricultural development is only possible with the active participation of smallholders; there are almost 500 million family farms in the world who produce 80 percent of its food. ${ }^{13}$ Contrary to widespread perceptions, smallholder farming is generally very productive. ${ }^{14}$

Yet, according to Oxfam's analysis, the overall proportion of EU ODA destined explicitly for smallholders is remarkably low. In planning documents, the average proportions of disbursed agricultural ODA that target smallholder farmers as a principal or significant objective are only 6.4 percent and 15.8 percent respectively ${ }^{15}$ (Figure 4 ). Consequently, little more than one-fifth of all EU ODA for agriculture is targeting smallholder farmers explicitly. The EU Food Facility had a positive effect on reaching smallholders, but disbursement quickly declined after 2010 in both absolute and relative terms. It is noteworthy that funds provided through NGOs (11 percent) and UN organizations (10.1 percent) exhibit the highest proportions of ODA principally targeting smallholders, whereas funding from the public sector averages just 4.1 percent. ${ }^{16}$ The in-depth analysis shows a slightly more positive outcome: 19 of the 25 projects analysed aimed to strengthen small-scale farming through at least one programme component (Table 1). However, smallholder support was a principal objective in only 20 percent of the projects. Combining the results of the two phases leads to the conclusion that less than onequarter of aid for agriculture explicitly targets small-scale producers, which is in stark contrast to the EU's own development policy agenda.

Channelling funds through the private sector did not play any major role in the period analysed. This is expected to change rapidly, however, as the EU policy to strengthen the role of the private sector in development cooperation, ${ }^{17}$ including in agriculture, is set in motion. Private sector cooperation and blended finance can provide additional funding and know-how for agriculture. However, the added value of private sector cooperation in aid activities still needs to be established more clearly. A cautious approach should be adopted to minimize risks and to ensure that private sector engagement does not come at the expense of empowering small-scale producers. For example, a recent resolution of the European Parliament was heavily critical of the New Alliance for Food Security and Nutrition in Africa, the private sector initiative by the G8, which has largely failed to deliver on its promise to lift 50 million people out of poverty, and has caused significant negative impacts for smallholders. ${ }^{18}$ 
Figure 4: EU ODA for agriculture in support of smallholder farmers (research phase 1)

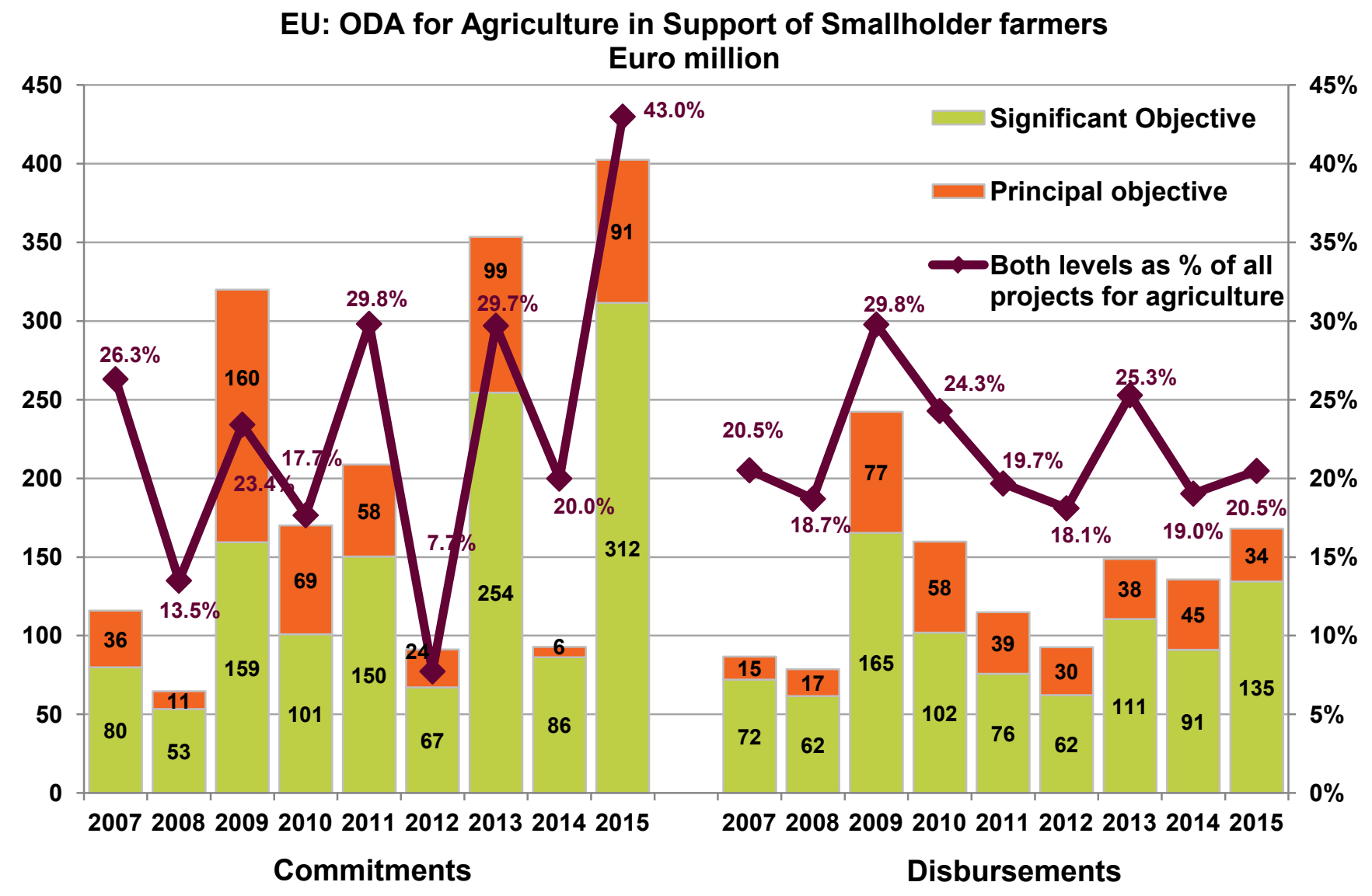

Table 1: Results of in-depth analysis of 25 EU-funded agriculture projects (research phase 2)

\begin{tabular}{|l|c|c|c|}
\hline $\begin{array}{l}\text { Support of policy } \\
\text { objectives }\end{array}$ & $\begin{array}{l}\text { Smallholder } \\
\text { support }\end{array}$ & Gender equality & $\begin{array}{l}\text { Ecological } \\
\text { sustainability }\end{array}$ \\
\hline Principal objective & $20 \%$ & $4 \%$ & $0 \%$ \\
\hline Significant objective & $56 \%$ & $75 \%$ & $56 \%$ \\
\hline No specific activity & $24 \%$ & $20 \%$ & $44 \%$ \\
\hline
\end{tabular}

\section{FAILURE TO PUT WOMEN FRONT AND CENTRE: MISSED CHANCES FOR POVERTY REDUCTION}

'A specific investment in women will be required.' - European Commission: EU policy framework on food security ${ }^{19}$

Women, who constitute around 43 percent of the agricultural labour force in developing countries, are generally disadvantaged, with fewer entitlements and endowments than their male counterparts. ${ }^{20}$ According to FAO estimates, ensuring equal access for women to land and other productive resources would boost farm productivity and lift $100-150$ million people worldwide out of hunger. ${ }^{21}$

Closing the gender gap has been a longstanding commitment of EU policy, as demonstrated by the 2005 European Consensus on Development ${ }^{22}$ and more recently by the adoption of the Gender Action Plan 2016-2020. ${ }^{23}$ Recognizing the many benefits of investing in female farmers, the EU has embarked on a pro-women agenda, stating 
that 'smallholder farmers, particularly women, are seen as likely to be the main agents in stepping up agriculture in EU food security cooperation policy'. ${ }^{24}$

In practice, however, women are not the primary targets of agriculture projects funded by EU money. In planning documents, funding targeted at gender equality as a principal objective compromises only 0.6 percent of all agriculture ODA, reaching a meagre 3.5 percent when flows that include gender equality as a significant objective are also taken into account ${ }^{25}$ (Figure 5). In sub-Saharan Africa, a region with one of the highest female participation rates in the agricultural workforce, the funding proportion for enhancing gender equality is even lower than average.

In the second phase of the research, gender equality was found to be a principal objective in only one project (Table 1). While gender equality was a significant objective in 19 projects, hardly any of them differentiated actions on the basis of women's specific needs resulting from their living conditions and social roles. Tailored project approaches to empower women farmers, and dedicated funding, are urgently needed to foster gender equality in agriculture.

Figure 5: EU ODA for agriculture in support of gender equality (research phase 1)

\section{EU: ODA for Agriculture in Support of Gender Equality Euro million}

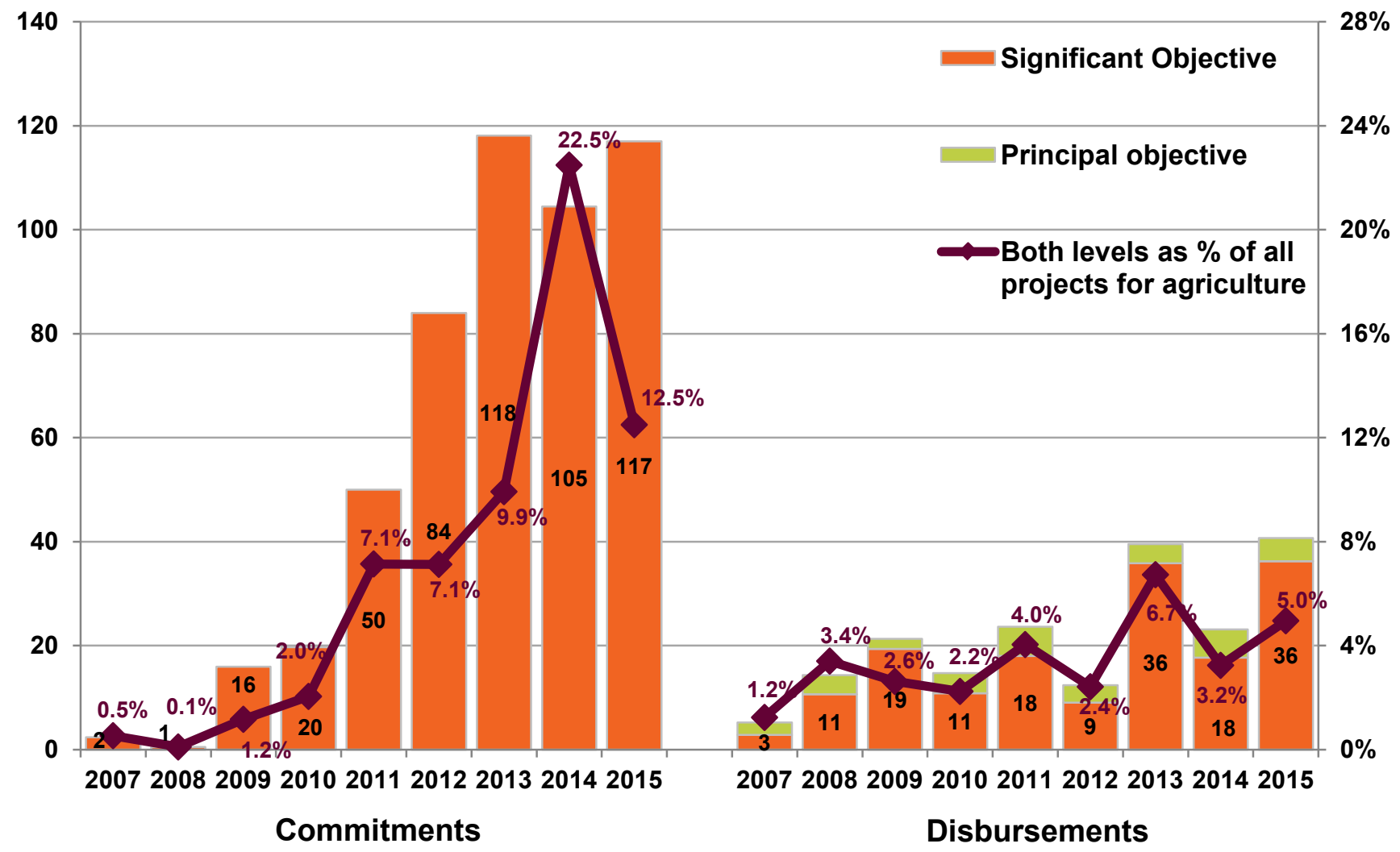

\section{RISKS OF EXACERBATING CLIMATE CHANGE}

'When supporting small-scale agriculture EU assistance should prioritise intensification approaches that are sustainable and ecologically efficient, respecting the diverse functions of agriculture.' - European Commission: EU policy framework on food security $^{26}$ 
Climate change is a threat to the global food system and brings unpredictable challenges to agriculture. Some 25 percent of damage caused by climate-related disasters is borne by the agriculture sector, with particularly adverse effects on the livelihoods of smallholders. ${ }^{27}$ Conversely, industrial-scale agriculture is one of the main drivers of climate change; it causes loss of biodiversity and accounts for more than half of noncarbon greenhouse gases (GHGs) ${ }^{28}$ It is recognized that mitigation of and adaptation to climate change depend to a great extent on the inclusive development of the small farm sector and climate-sensitive approaches such as agro-ecology. ${ }^{29}$ When the Paris Agreement was struck in 2015, EU countries played an important role in the commitment to limiting global warming and succeeded in getting food security and food systems recognized in it.

Unfortunately, the proportion of funding geared towards sustainable management of resources is marginal compared with the magnitude of the challenges. The results of the first phase of this research indicate that, overall, a mere 1.6 percent of funding as a principal objective and 3.3 percent as a principal or significant objective combined ${ }^{30}$ was destined specifically to improve ecological sustainability in farming practices (Figure 6). In the second phase, 11 of the 25 projects omitted the dimension of ecological sustainability altogether (Table 1). Dismally, ecological sustainability was not a principal objective in any of the projects; however, 14 projects considered this dimension in their evaluation reports. The main activities relating to ecological sustainability included soil conservation, prevention of water erosion, water conversation and, to a lesser extent, the use of specific farming techniques such as conservation agriculture or the use of organic fertilizers. However, the bulk of project evaluations did not discuss the impacts of climate change in relation to the projects; this is a poor record for projects financed by a global leader in the fight against climate change.

Figure 6: EU ODA for agriculture in support of ecological sustainability (research phase 1)

\section{EU: ODA for Agriculture in Support of Ecological Sustainability Euro million}

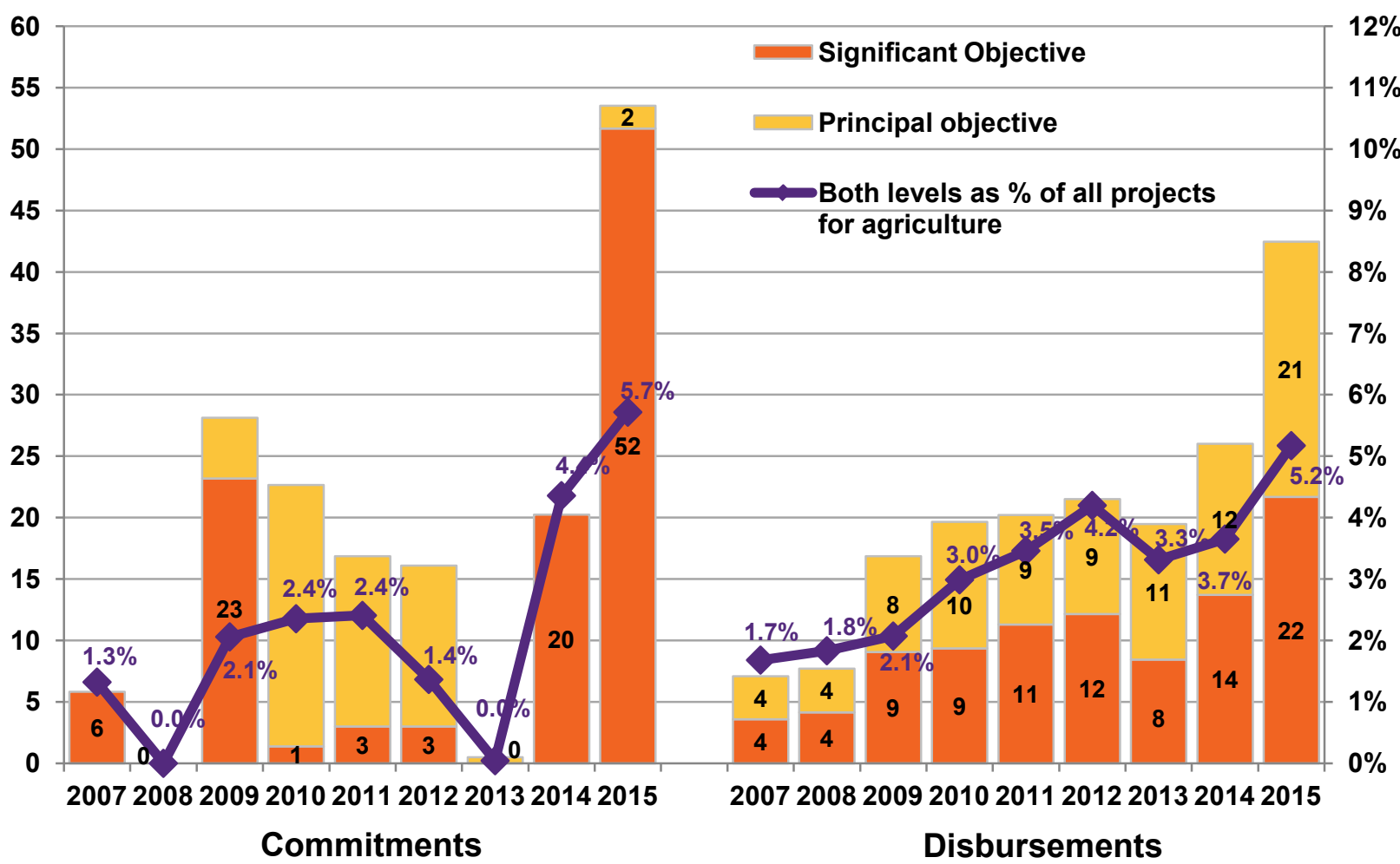


Box 1: Food and Nutrition Security Programme in Burkina Faso (Programme de Sécurité Alimentaire et Nutritionnelle au Burkina Faso, PSANBF) ${ }^{31}$

The Environmental and Social Assessment of the Food and Nutrition Security Programme in Burkina Faso (PSANBF) points to conflicts between the goals of improving livelihoods and protecting the environment. The primary objective of the programme was to improve food security through a number of actions, including the construction of wells and the introduction of new seeds and fertilizers. However, some of the programme's initiatives risk backfiring because environmental aspects were not sufficiently taken into account. While new irrigation systems and pesticides for lowland agriculture have led to improved food security and incomes and greater autonomy for women farmers in the short term, negative impacts on the environment might reverse this trend in the long term. These include fragmentation and destruction of habitat and pasture, loss of natural resources due to clearing, degradation of water resources due to the excessive use of fertilizers, and adverse effects on health and biodiversity caused by increased use of pesticides. Likewise, the donation of 9,000 small livestock animals has improved beneficiaries' incomes in the short term, but has created additional pressures on the environment.

\section{THE LARGEST RECIPIENT OF EU AGRICULTURAL ODA IS EUROPE AND ITS NEIGHBOURHOOD}

'EU action needs to give priority to those food insecure countries most off-track in reaching MDG1, in particular in Africa, but also South Asia and elsewhere.' - European Commission: EU policy framework on food security ${ }^{32}$

Food insecurity has a strong geographical dimension, with sub-Saharan Africa being by far the worst affected region. Approximately one out of every four people in sub-Saharan Africa is undernourished. ${ }^{33}$ In recent years the EU has been shifting to a greater commitment to a rights-based approach to development cooperation, ${ }^{34}$ the principle of impartiality and response according to need. This also applies to the EU FSPF, which clearly supports the prioritization of ODA for countries facing the greatest challenges in eradicating extreme poverty and hunger.

In contrast with these commitments, however, the aid volumes earmarked for encouraging agricultural development on the African continent declined considerably in the aftermath of the emergency response led by the Food Facility. The share of agriculture ODA for the region fell to a low point of 45 percent in 2015. Conversely, flows to ODA recipients in Europe ${ }^{35}$ have grown 10-fold since 2009, at the expense of other regions. Taking population size into account, European recipient countries have overtaken sub-Saharan Africa in four of the last five years. In 2015, the EU disbursed $€ 1.29$ for every citizen living in European ODA recipient countries, and just $€ 0.35$ per person for those living in sub-Saharan Africa.

The analysis of agricultural aid allocation reveals a substantial inconsistency. On the one hand, the overall distribution appears to be in line with differing degrees of need, giving on average higher priority to those countries that exhibit a higher risk of food insecurity. On the other hand, the preference for countries identified as being potential future EU members or those located in the European neighbourhood has ultimately led to striking distortions of the distribution structure. 
Figure 7: EU ODA disbursements for agriculture per capita by regions

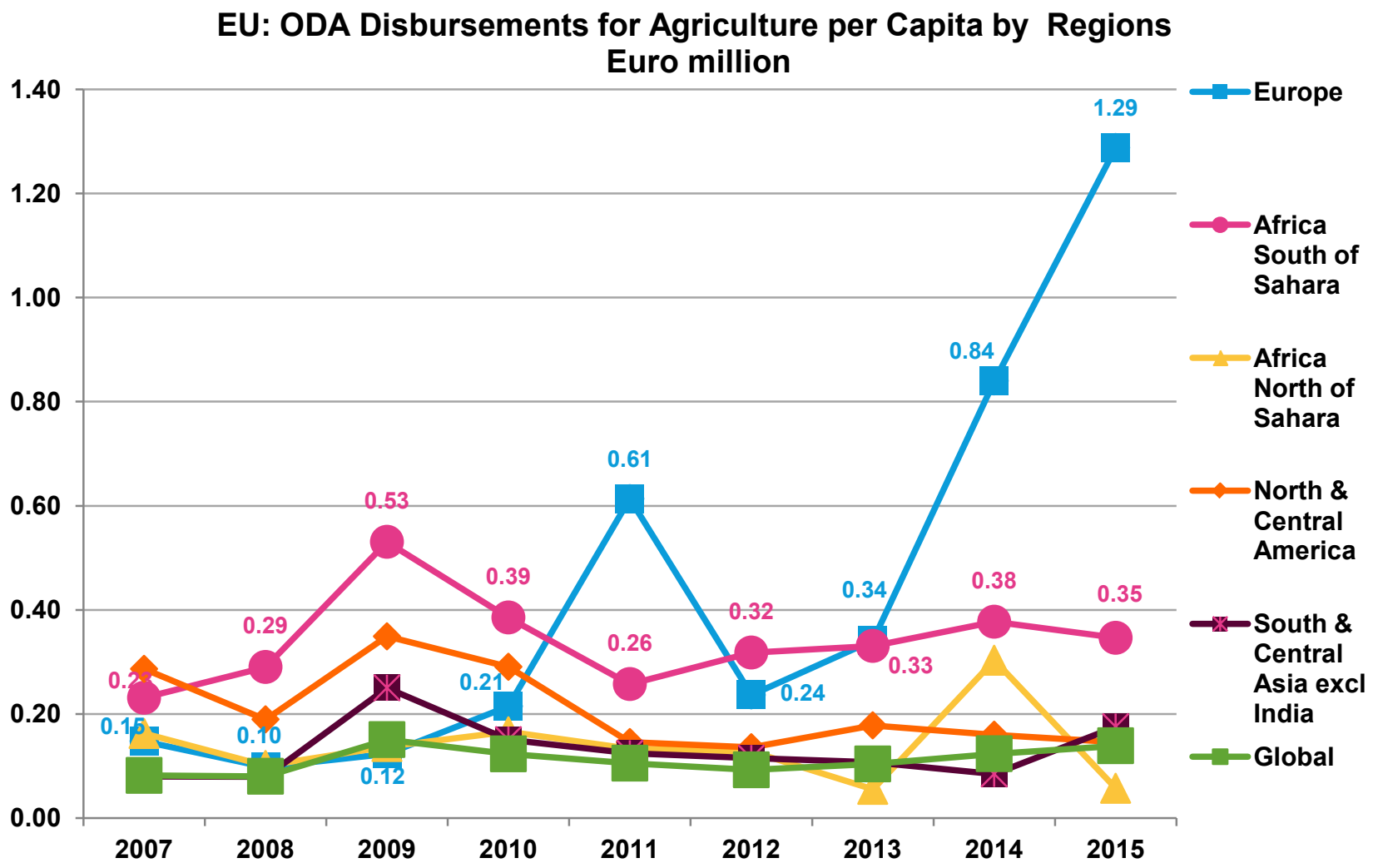

\section{RECOMMENDATIONS}

Based on the research results, Oxfam makes the following recommendations for the European Union's ODA investment in the agricultural sector, so that it better supports the empowerment of small-scale producers for food security and resilience.

\section{Deliver on existing EU food security commitments}

- Empower small-scale producers: While the EU has explicitly and repeatedly recognized the potential that small-scale farming holds, funding that targets this critical population group in an explicit manner represents a strikingly low proportion of its overall agriculture ODA. The EU should increase both its commitments and its disbursements in support of small-scale producers who are frequently excluded, responding in particular to the needs of women and youth. To increase accountability, the target groups need to be consistently involved in the design, implementation and monitoring of projects.

- Promote gender equality: The central role of women and the necessity to unlock their potential in agricultural development are recognized, yet not put into practice. Supporting equal access for women to productive resources, including land, and tackling structural and cultural barriers to gender equality require the empowerment of women to be placed at the heart of the EU's agricultural development agenda. Gender equality should be mainstreamed and should be consistently present as a principal objective in agriculture projects. This should involve supporting gender budgeting in partner countries and upscaling support to women's production groups, as well as women's rights organizations. 
- Support only ecologically sustainable agriculture models: In the face of the huge challenges posed by climate change, the EU's explicit efforts to support ecological sustainability are inadequate. The EU should limit the risk of seeking increased agricultural productivity at the expense of protection of the environment and sustainable use of resources. Ecologically sustainable approaches, including agroecology, should be prioritized in its agricultural development policy and practice, and the ecological dimension mainstreamed throughout agricultural development activities.

\section{Support partner countries to meet their agricultural commitments}

- Support countries to respect the Malabo Declaration: Only a small number of African Union member states are able to meet their agriculture budget commitments under the Malabo Declaration, and many partner governments earmark only a marginal portion of the EU's general budget support to the agricultural sector. The EU should strengthen sustainable agriculture and food security as a focal sector of cooperation, especially in those partner countries facing food crises, and it should support governments to allocate at least 10 percent of their national budgets to the agricultural sector. The funding should go to benefit small-scale producers, placing female farmers and the integration of youth at the centre of development efforts.

- Set the governance context: The EU should take into account local socio-political contexts in its programming and should foster a structural approach, especially in partner countries that are chronically food-insecure. It should prioritize addressing the underlying causes of food and nutrition insecurity rather than the consequences and place governance issues at the core of policy dialogue, with the aim of reducing structural vulnerability in the long run. Apart from investments, the EU should develop policy tools that governments can use to create an enabling environment for farmers and their rights and to support an inclusive agricultural transformation - including reducing power imbalances and supporting national-level land reforms.

\section{Maintain the integrity of agricultural aid as a tool to eradicate poverty and ensure food security}

- Do not instrumentalize agricultural aid: Since 2009, agriculture ODA flows to recipient countries in Europe have grown 10-fold at the expense of other regions, including sub-Saharan Africa. The EU's foreign policy objectives should not determine the country allocation of agricultural ODA. Instead, aid should be directed to countries and regions where it is most needed, keeping the levels of support consistent and predictable to allow for long-term planning. Significant fluctuations in EU ODA flows cast doubt on the consistency of its support for this critical development goal.

- Adopt a cautious approach to private sector cooperation and blended finance: Recent EU policy developments have paved the way for a stronger role for the private sector in development, including in the mobilization of development finance. While this opens up new opportunities, the added value of private sector cooperation in aid activities is still unclear. The EU should only engage in private finance blending when it can demonstrate financial and development additionality, effective minimization of risks for people and the environment, promotion of women's rights and economic opportunities, and a strengthening rather than undermining of the public sector. Private sector engagement should not come at the expense of maintaining the focus of agricultural development on smallholders. 


\section{Adopt best practices for transparency and accountability}

- Develop better mechanisms for monitoring and evaluating policy implementation: The progress and results reports that have been published by the European Commission since 2014 are a move in the right direction in assessing how EU policy is translated into action. They should be further developed into a more comprehensive and consistent monitoring mechanism to ensure that the EU policy framework to assist developing countries in addressing food security challenges is implemented on the ground.

- Address ODA reporting problems and improve access to project data in donor databases: There are significant problems involved in accessing project data and documents in the information systems on aid activities. The quality of the EU's ODA reporting should be improved by implementing the common, open standard for the publication of timely, comprehensive and forward-looking information, as set out by the OECD Working Party on Development Finance Statistics (WP-STAT) and the International Aid Transparency Initiative (IATI). Project planning documents, evaluation reports and other progress reports should be made available online, with easy access through clear identification numbers or codes.

\section{Prioritize food security and small-scale agriculture in the post-2020 Multiannual Financial Framework}

- The impending four famines and the high number of chronically malnourished people worldwide demonstrate that food and nutrition security continues to be an important global development challenge. The EU, as a leading donor institution, should play its part by investing additional financial resources beyond the current levels. Food security and sustainable agriculture should remain a priority sector of intervention in the EU's Multiannual Financial Framework in the years beyond 2020, and the EU should strengthen its efforts to tackle the structural causes of food insecurity, including by providing substantial and tailored support for the empowerment of women smallscale producers.

\section{NOTES}

1 Food Security Information Network (FSIN) (2017). Global Report on Food Crises 2017.

2 Food and Agriculture Organisation of the United Nations (FAO) (2015). The State of Food Security in the World. Meeting the 2015 international hunger targets: taking stock of uneven progress.

3 FAO (2016). The State of Food and Agriculture. Climate Change, Agriculture, and Food Security.

4 A more comprehensive and detailed methodology, along with the dataset, is available upon request.

5 An interactive visualization tool with maps and charts is available online to explore the main results and indicators of the research by recipient countries. See: http://odaforhealth.medmissio.de/volumes_oda_transfers_agriculture_rec_country/web/StatPlanet.html

6 European Commission (2010). Communication from the Commission to the Council and the European Parliament. An EU policy framework to assist developing countries in addressing food security challenges. SEC(2010)379.

7 United Nations, Development Initiatives and UK Aid (2015). Improving ODA Allocation for a Post-2015 World: Targeting aid to benefit the poorest $20 \%$ of people in developing countries, p. 25 . http://devinit.org/wp-content/uploads/2015/01/DI_UN_Improving-ODA-allocation-for-a-post-2015-world_21January-20151.pdf

8 International Food Policy Research Institute (IFPRI) and International Institute for Sustainable Development (ISSD) (2016). Ending Hunger: What would it cost?

9 African Union (2014). Malabo Declaration on Accelerated Agricultural Growth and Transformation for Shared Prosperity and Improved Livelihoods.

10 United Nations, Development Initiatives and UK Aid (2015). Improving ODA Allocation for a Post-2015 World, op. cit., p.25. 
11 Regional Strategic Analysis and Knowledge Support System (ReSAKSS). Annual Trends and Outlook Report (2012). Complying with the Maputo Declaration Target. Trends in public agricultural expenditures and implications for pursuit of optimal allocation of public agricultural spending.

12 European Commission (2010). Communication from the Commission to the Council and the European Parliament. An EU policy framework to assist developing countries in addressing food security challenges. SEC(2010)379.

13 FAO (2014). The State of Food and Agriculture 2014: Innovation in family farming.

14 FAO (2013). Investing in Smallholder Agriculture for Food Security: A Report by the High Level Panel Experts on Food Security and Nutrition.

15 The percentages represent the weighted averages for the period 2007-15.

16 The percentages represent the weighted averages for the period 2007-15.

17 European Commission (2014). Communication from the Commission to the European Parliament, the Council, the European Economic and Social Committee and the Committee of the Regions: A Stronger Role of the Private Sector in Achieving Inclusive and Sustainable Growth in Developing Countries.

18 European Parliament resolution of 7 June 2016 on the New Alliance for Food Security and Nutrition (2015/2277(INI)).

19 European Commission (2010). Communication from the Commission to the Council and the European Parliament. An EU policy framework to assist developing countries in addressing food security challenges. SEC(2010)379,.

20 FAO (2016). The State of Food and Agriculture: Climate Change, Agriculture and Food Security, op. cit.

21 FAO (2011). The State of Food and Agriculture 2010-2011. Women in Agriculture: Closing the gender gap for development.

22 European Union (2005). Joint statement by the Council and the representatives of the governments of the Member States meeting within the Council, the European Parliament and the Commission on European Union Development Policy: 'The European Consensus'.

23 European Commission (2016). EU Gender Action Plan 2016-2020.

24 European Commission (2012). Sustainable Agriculture for the Future We Want.

25 The percentages represent the weighted averages for the period 2007-15.

26 European Commission (2010). Communication from the Commission to the Council and the European Parliament. An EU policy framework to assist developing countries in addressing food security challenges. SEC(2010)379.

27 FAO (2015). The Impact of Natural Hazards and Disasters on Agriculture, Food and Nutrition Security: A Call for Action to Build Resilient Livelihoods.

28 P. Smith et al. (2014). Agriculture, Forestry and Other Land Use (AFOLU). Climate Change 2014: Mitigation of Climate Change. Contribution of Working Group III to the Fifth Assessment Report of the Intergovernmental Panel on Climate Change.

29 This is 'the science of applying ecological concepts and principles to the design and management of sustainable agroecosystems'; see Oxfam (2014). Building a New Agricultural Future: Supporting agroecology for people and planet.

30 The percentages represent the weighted averages for the period 2007-15.

31 European Union, EU and Consortium AGRECO (2012). Programme de Sécurité Alimentaire et Nutritionnelle, Burkina Faso: Evaluation Environnementale et Sociale Stratégique. Rapport final EESS.

32 European Commission (2010). Communication from the Commission to the Council and the European Parliament. An EU policy framework to assist developing countries in addressing food security challenges. SEC(2010)379.

33 FAO (2015). Regional Overview of Food Insecurity: Africa.

34 Council of the European Union (2014). Council conclusions on a rights-based approach to development cooperation, encompassing all human rights.

35 Albania, Belarus, Bosnia and Herzegovina, Croatia, Kosovo, Moldova, Montenegro, Serbia, Turkey, Ukraine. 
This paper was written by Jan Mayrhofer and Hanna Saarinen, based on in-depth research conducted by Joachim Rüppel (main researcher) and Tilman Rüppel (research assistant) at the Medical Mission Institute. Oxfam acknowledges the assistance of Hervé Busschaert, Hugo Hooijer, Clara Jamart, Hilary Jeune and Eric Muñoz.

For further information on the issues raised in this paper please email hanna.saarinen@oxfam.org

This publication is copyright but the text may be used free of charge for the purposes of advocacy, campaigning, education, and research, provided that the source is acknowledged in full. The copyright holder requests that all such use be registered with them for impact assessment purposes. For copying in any other circumstances, or for re-use in other publications, or for translation or adaptation, permission must be secured and a fee may be charged. Email policyandpractice@oxfam.org.uk

The information in this publication is correct at the time of going to press.

Published by Oxfam GB for Oxfam International under ISBN 978-1-78748-012-4 in June 2017. Oxfam GB, Oxfam House, John Smith Drive, Cowley, Oxford, OX4 2JY, UK.

The overarching goal of the Medical Mission Institute is to strengthen human solidarity for improving health services and conditions, in particular supporting disadvantaged people. The Institute works together with faith-based and civil society organizations, contributing with consultancy and research services as well as engaging in political advocacy. For more than a decade, studies and publications on development assistance provided by European countries and EU institutions for health and related themes have been central areas of its work. See http://english.medmissio.de/.

\section{OXFAM}

Oxfam is an international confederation of 20 organizations networked together in more than 90 countries, as part of a global movement for change, to build a future free from the injustice of poverty. Please write to any of the agencies for further information, or visit www.oxfam.org

Oxfam America (www.oxfamamerica.org)

Oxfam Australia (www.oxfam.org.au)

Oxfam-in-Belgium (www.oxfamsol.be)

Oxfam Brasil (www.oxfam.org.br)

Oxfam Canada (www.oxfam.ca)

Oxfam France (www.oxfamfrance.org)

Oxfam Germany (www.oxfam.de)

Oxfam GB (www.oxfam.org.uk)

Oxfam Hong Kong (www.oxfam.org.hk)

Oxfam IBIS (Denmark) (www.ibis-global.org)

Oxfam India (www.oxfamindia.org)

Oxfam Intermón (Spain)

(www.intermonoxfam.org)

Oxfam Ireland (www.oxfamireland.org)

Oxfam Italy (www.oxfamitalia.org)
Oxfam Japan (www.oxfam.jp)

Oxfam Mexico (www.oxfammexico.org)

Oxfam New Zealand (www.oxfam.org.nz)

Oxfam Novib (Netherlands)

(www.oxfamnovib.nl)

Oxfam Québec (www.oxfam.qc.ca)

Oxfam South Africa (www.oxfam.org.za) 